\title{
A Specific DNA Probe for the Identification of Campylobacter jejuni
}

\author{
By VICTORIA KOROLIK, ${ }^{1}$ PETER J. COLOE ${ }^{2}$ AND \\ VIJI KRISHNAPILLAI ${ }^{1}{ }^{*}$ \\ ${ }^{1}$ Department of Genetics, Monash University, Clayton 3168, Victoria, Australia \\ 2 Department of Applied Biology, Royal Melbourne Institute of Technology, 124 La Trobe Street, \\ Melbourne 3000, Victoria, Australia
}

(Received 14 April 1987; revised 10 September 1987)

\begin{abstract}
A 6.1 kb DNA probe for the human enteric pathogen Campylobacter jejuni has been isolated from a genomic library constructed in the plasmid vector pBR322 in Escherichia coli. The DNA sequence used as a probe was identified from recombinant plasmids following immunological screening of transformants using polyclonal antisera to whole cells and to membrane antigens of $C$. jejuni. Restriction endonuclease fragment mapping of $C$. jejuni DNA inserts from three of the recombinant plasmids showed an overlapping DNA fragment. One of these recombinant plasmids, when used as a DNA probe in Southern hybridization, specifically hybridized with chromosomal DNA from all of the $C$. jejuni strains tested. Hybridization was not detected at high stringency between the DNA probe and chromosomal DNA from any other Campylobacter species tested except weakly with the chromosomal DNA of strains of Campylobacter coli. Hybridization was also not detected with chromosomal DNA from a range of other enteric bacteria likely to be encountered in faecal material. The intensity of hybridization with $C$. coli could be increased by reducing the stringency of hybridization.
\end{abstract}

\section{INTRODUCTION}

Acute gastroenteritis due to Campylobacter jejuni infections has become a major cause of human diarrhoeal disease worldwide (Blaser \& Reller, 1981; Skirrow, 1982). The isolation and cultivation of $C$. jejuni from faeces require specialized media containing antibiotics for selection and supplements for enrichment, strict microaerophily and specialized media for their transport to the laboratory (Skirrow et al., 1982). The identification of $C$. jejuni and its characterization are based on a number of different criteria including biochemical tests, serological analysis, restriction endonuclease DNA fingerprinting, membrane protein profiling and DNA-DNA hybridization (Skirrow et al., 1982; Hébert et al., 1982; Blaser et al., 1983; Penner et al., 1983; Bradbury et al., 1984; Owen \& Dawson, 1986). Thus its cultivation and identification are timeconsuming.

In the context of instituting immediate chemotherapeutic measures in acute cases of infection it would be highly desirable to have a technique which can rapidly and reliably identify $C$. jejuni directly from clinical material (faeces) without recourse to cultivation and subsequent identification by one or more of the conventional methods. Potentially, this may be provided by the use of specific DNA probes for the rapid and reliable identification of $C$. jejuni. DNA probes are now being developed for the diagnosis and epidemiology of a range of bacterial infections including those caused by Legionella pneumophila and Salmonella typhi (Grimont et al., 1985; Rubin et al., 1985).

A strategy for Campylobacter probes has been reported (Rashtchian et al., 1986). However, of the two synthetic oligonucleotide probes based on $C$. jejuni 16S rRNA sequences, one was unable

Abbreviations: Ap, ampicillin; Tc, tetracycline. 
to distinguish between $C$. jejuni, $C$. coli and $C$. laridis whereas the second hybridized to all Campylobacter species tested. Nick-translated random chromosomal DNA fragments from Campylobacter species have also been used in their epidemiology (Steele et al., 1985). This paper reports the construction of a specific DNA probe for $C$. jejuni by the cloning of a $C$. jejuni DNA sequence into the plasmid vector pBR322 as the first step in the development of rapid and reliable probes for $C$. jejuni. The feasibility of constructing such probes has been reported in a preliminary communication (Claus et al., 1982).

\section{METHODS}

Bacterial strains and plasmids. These are shown in Table 1.

Cultural conditions. Campylobacter species were grown on Oxoid Columbia Agar supplemented with $7 \%(\mathrm{v} / \mathrm{v})$ defibrinated horse blood, for $48-72 \mathrm{~h}$ at $37{ }^{\circ} \mathrm{C}$ in a gaseous atmosphere of $90 \% \mathrm{~N}_{2}, 5 \% \mathrm{CO}_{2}$ and $5 \% \mathrm{O}_{2}$. All other bacteria were grown on Oxoid Blood Agar Base supplemented with $0.5 \%$ Oxoid yeast extract or in Oxoid Nutrient Broth no. 2 supplemented with $0.5 \%$ Oxoid yeast extract for $18 \mathrm{~h}$ at $37^{\circ} \mathrm{C}$.

Antibiotics. Ampicillin (Ap; Beecham) and oxytetracycline hydrochloride (Tc; Sigma) were used at $200 \mu \mathrm{g} \mathrm{ml}^{-1}$ and $60 \mu \mathrm{g} \mathrm{ml}^{-1}$, respectively.

Antisera. Bacteria for antigen preparations were prepared by harvesting the confluent growth of $72 \mathrm{~h} \mathrm{C}$. jejuni cultures grown on 20 horse blood agar plates under appropriate gaseous conditions. Cells were washed from the plate with $0.1 \mathrm{M}$-Tris $/ \mathrm{HCl}$ buffer $(\mathrm{pH} 8.3$ ). After washing twice with $0.1 \mathrm{M}-\mathrm{Tris} / \mathrm{HCl}$ buffer, the bacteria were suspended in a final volume of $25 \mathrm{ml} 0 \cdot 1 \mathrm{M}$-Tris/ $\mathrm{HCl}$ buffer. For whole cell antigens, $5 \mathrm{ml}$ of the cell suspension was lightly sonicated and stored at $-20^{\circ} \mathrm{C}$. For membrane antigens the membranes were prepared using the lysozyme-EDTA extraction procedure as described by Mills \& Bradbury $(1984)$ and stored at $-20^{\circ} \mathrm{C}$. They were checked for purity by SDS-PAGE (Laemmli, 1970). Both whole cell and membrane antisera were tested and confirmed to possess antibodies that reacted with membrane antigens in the Western immunoblotting procedure (Towbin et al., 1979).

For production of antisera adult New Zealand White rabbits were immunized with $1 \mathrm{ml}$ whole cell or membrane antigens mixed with an equal volume of Freund's complete adjuvant (Commonwealth Serum Laboratories) and injected into two sites in the hindquarter muscles. Booster doses of the antigens in Freund's incomplete adjuvant were administered in a similar manner on days 14,28 and 56 . Sera were collected on day 70 and stored. Prior to use, antisera diluted $1 / 50 \mathrm{in} 10 \mathrm{~mm}-\mathrm{Tris} / \mathrm{HCl}$ (pH 7.5), were absorbed with viable cells of $E$. coli strain $\mathrm{DH} 1$ and grown confluently on three agar plates to remove $E$.-coli-specific antibodies. The absorptions were done three times for $24 \mathrm{~h}$ at $4{ }^{\circ} \mathrm{C}$.

Chromosomal DNA extraction. Bacteria harvested from agar plates into $10 \mathrm{mM}-\mathrm{Tris} / \mathrm{HCl}(\mathrm{pH} 7.5)$ were used and DNA was extracted by the method described by Collins \& Ross (1984).

Plasmid DNA extraction, purification, restriction endonuclease digestion and agarose gel electrophoresis. These were done as described previously (Krishnapillai et al., 1984). Conditions of restriction endonuclease digestion were as recommended by the manufacturer except that with Campylobacter DNA, 20-30 units of enzyme were used to digest $1 \mu \mathrm{g}$ DNA. BglII was from Promega Biotec; $E c o$ RV and HindIII were from New England Biolabs; ClaI, PvuII, Sau3A and BamHI were from Boehringer Mannheim.

Construction of a C. jejuni genomic library. This was done as described by Maniatis et al. (1982).

Immunological screening of the C. jejuni library. Transformants of $E$. coli strain DH1 were screened for recombinant plasmids expressing $C$. jejuni antigens by colony blotting with $C$. jejuni antisera. Transformants were transferred by replica-plating to nitrocellulose filters $(0.45 \mu \mathrm{m}$; Biorad), lysed in situ in $0.2 \mathrm{M}-\mathrm{NaOH}$ for $30 \mathrm{~min}$, washed sequentially in $50 \%, 70 \%$ and $95 \%(\mathrm{v} / \mathrm{v})$ ethanol and dried. Non-reactive sites were blocked with $5 \%(\mathrm{w} / \mathrm{v})$ skim milk in $10 \mathrm{mM}$-Tris/ $\mathrm{HCl}$ buffer $(\mathrm{pH} 7.5)$ and $0.05 \%$ (w/v) Tween 20 for $30 \mathrm{~min}$ at $37^{\circ} \mathrm{C}$. Filters were then incubated with antisera (either to whole cells or to membranes) diluted $1 / 200$ in $10 \mathrm{mM}-\mathrm{Tris} / \mathrm{HCl}$ buffer $(\mathrm{pH} 7 \cdot 5)$ and $0.05 \%(\mathrm{w} / \mathrm{v})$ Tween 20 for $60 \mathrm{~min}$ at $37^{\circ} \mathrm{C}$. They were washed and incubated with goat anti-rabbit IgG conjugated with horse-radish peroxidase (Biorad) for $60 \mathrm{~min}$ at $37^{\circ} \mathrm{C}$. Positive signals were identified using 4chloro-1-naphthol (Biorad) as a chromogenic substrate.

Preparation of nick-translated probe DNA. DNA was radio-labelled in vitro using $[\alpha-32 \mathrm{P}] \mathrm{dATP}$ (Bresa) as described by Maniatis et al. (1982), to a specific activity of $10^{6}-10^{7}$ c.p.m. ( $\mu$ g DNA)-1 except that labelled DNA was collected by ethanol precipitation and unincorporated nucleotides were removed by washing the pellet sequentially with $70 \%$ and $100 \%$ ethanol.

Southern hybridization. Chromosomal DNA (1-2 $\mu \mathrm{g})$ was digested with appropriate restriction endonucleases and DNA fragments separated by horizontal agarose gel electrophoresis. The fragments were then transferred bidirectionally to Hybond-N nylon filters $(0.45 \mu \mathrm{m}$; Amersham) for $2-4 \mathrm{~h}$ as described by Smith \& Summers (1980). The filters were then used in hybridizations as described by Maniatis et al. (1982) with the following modifications. Pre-hybridizations were done for $2-4 \mathrm{~h}$ at $65^{\circ} \mathrm{C}$ in SSCP solution, $\mathrm{pH} 7.2(600 \mathrm{mM}-\mathrm{NaCl}, 60 \mathrm{mM}-$ trisodium citrate, $50 \mathrm{mM}-\mathrm{KH}_{2} \mathrm{PO}_{4}, 4 \mathrm{mM}$-EDTA) supplemented with $5 \times$ Denhardt's solution $(0 \cdot 1 \%$ Ficoll, $0.1 \%$ 
Table 1. Bacterial strains and plasmids

\begin{tabular}{|c|c|c|c|}
\hline Bacteria & $\begin{array}{c}\text { Strain } \\
\text { no. }\end{array}$ & $\begin{array}{l}\text { Country } \\
\text { of origin }\end{array}$ & $\begin{array}{l}\text { Source or } \\
\text { reference* }\end{array}$ \\
\hline $\begin{array}{l}\text { Campylobacter jejuni } \\
\text { Campylobacter jejuni }\end{array}$ & FFl & & A \\
\hline Campylobacter jejuni & FF2 & & A \\
\hline Campylobacter jejuni & FF3 & Australia & A \\
\hline Campylobacter jejuni & FF6 & & A \\
\hline Campylobacter jejuni & CSIRO 18 & & A \\
\hline Campylobacter jejuni & NCTC 11351 & & B \\
\hline Campylobacter jejuni & D114 & Japan & $\mathrm{C}$ \\
\hline Campylobacter jejuni & D117 & USA & $\mathrm{C}$ \\
\hline Campylobacter jejuni & D123 & Canada & $\mathrm{C}$ \\
\hline Campylobacter jejuni & 396 & Australia & D \\
\hline Campylobacter jejuni $\dagger$ & $80-104$ & USA & $\mathrm{E}$ \\
\hline Campylobacter coli & NCTC 11366 & & B \\
\hline Campylobacter coli & 900 & Australia & D \\
\hline Campylobacter laridis & NCTC 11352 & & B \\
\hline Campylobacter laridis & 011 & Australia & D \\
\hline Campylobacter fetus subsp. fetus & NCTC 10842 & & B \\
\hline Campylobacter fetus subsp. fetus & $80-256$ & USA & E \\
\hline 'Campylobacter fetus subsp. venerealis' & NCTC 10354 & & B \\
\hline $\begin{array}{l}\text { 'Campylobacter fetus subsp. venerealis' } \\
\text { 'Campylobacter fecalis' }\end{array}$ & D1133 & USA & C \\
\hline Campylobacter fecalis' & NCTC 11415 & & B \\
\hline Campylobacter pyloridis & P2 & Australia & A \\
\hline Salmonella enteritidis & G516 & & F \\
\hline Salmonella typhimurium & G505 & & F \\
\hline Escherichia coli $\mathrm{O} 111$ :K58(B4) & G108 & & F \\
\hline Shigella sonnei & G604 & & F \\
\hline Enterobacter cloacae & G402 & & $\mathrm{F}$ \\
\hline Citrobacter freundii & G201 & & $\mathbf{F}$ \\
\hline Klebsiella pneumoniae & G309 & & $\mathrm{F}$ \\
\hline Proteus vulgaris & G701 & & $\mathbf{F}$ \\
\hline Vibrio parahaemolyticus & $\mathrm{L} 102$ & & $\mathbf{F}$ \\
\hline Serratia marcescens & G802 & & $\mathrm{F}$ \\
\hline Pseudomonas aeruginosa & PAO1 & & G \\
\hline Escherichia coli & DH $1 \ddagger$ & & Frey et al. (1983) \\
\hline Plasmids & Icteristics & & $\begin{array}{l}\text { Source or } \\
\text { reference }\end{array}$ \\
\hline$A p^{R} T^{R}$ & & & Bolivar et al. (1977) \\
\hline $\mathrm{Ap}^{\mathrm{R}} \mathrm{pBR} 322 \Omega[C$. jejun & NA, Sau3A: $7 \cdot 4 \mathrm{~kb}]$ & & This study \\
\hline $\mathrm{Ap}^{\mathrm{R}} \mathrm{pBR} 322 \Omega[C$. jejun & NA, Sau3A :6.5 kb] & & This study \\
\hline $\mathrm{Ap}^{\mathrm{R}} \mathrm{pBR} 322 \Omega[C$. jejun & NA, Sau3A :6.1 kb] & & This study \\
\hline
\end{tabular}

* The source of the strains were as follows: A, Strain collection, Department of Applied Biology, Royal Melbourne Institute of Technology, Melbourne, Victoria 3000, Australia; B, type strains from the National Collection of Type Cultures, London, United Kingdom received from W. Tee, Department of Clinical Pathology, Fairfield Infectious Diseases Hospital, Fairfield, Victoria 3078, Australia; C, C. M. Patton, Hospital Infectious Program, Centres for Disease Control, Atlanta, Georgia 30333, USA; D, T. W. Steele, Institute of Medical and Veterinary Science, Adelaide, South Australia 5000, Australia; E, M. J. Blaser, Infectious Disease Section, Veterans Administration, Denver, Colorado 80220, USA; F, Strain collection, Department of Microbiology, Monash University, Clayton, Victoria 3168, Australia; G, strain collection, Department of Genetics, Monash University, Clayton, Victoria 3168, Australia.

$\dagger C$. jejuni strain 80-104 was received by us as $C$. coli strain 80-104. However, in Southern hybridization with the probe pMO2005 the band specificity was identical to that shown by the other $C$. jejuni strains (data not shown). It was also unable to hydrolyse hippurate like typical $C$. jejuni strains and unlike $C$. coli strains. For these reasons we refer to strain 80-104 as $C$. jejuni.

$\ddagger$ recAl endAl gyrA96 thi-1 hsdRI7 $\left(\mathrm{r}^{-} \mathrm{m}^{+}\right)$supE44 $\lambda^{-}$[gene symbols according to Bachmann (1983)].

polyvinylpyrrolidone, $0.1 \%$ bovine serum albumin fraction $\mathrm{V}$ ) and $0.1 \%$ SDS, $0.002 \%$ tRNA and $100 \mu \mathrm{g}$ denatured salmon sperm DNA ml-1. Hybridizations were done for $24 \mathrm{~h}$ at $65^{\circ} \mathrm{C}$ using $1-1.5 \mu \mathrm{g}$ labelled DNA in a fresh volume of the same solution. The filters were washed to remove non-hybridized probe as follows: in $2 \times$ SSC $\left(0.3 \mathrm{M}-\mathrm{NaCl}, 0.03 \mathrm{M}\right.$-trisodium citrate for $15 \mathrm{~min}$ at $65^{\circ} \mathrm{C}$, twice; in $2 \times \mathrm{SSC}$ with $0.1 \% \mathrm{SDS}$ for $30 \mathrm{~min}$ at $65^{\circ} \mathrm{C}$; 
and finally in $0.1 \times \mathrm{SSC}$ for $15 \mathrm{~min}$ at $65^{\circ} \mathrm{C}$ to maintain high stringency conditions. The filters were air-dried and autoradiograms were exposed to X-ray film (Fuji) for $6-72 \mathrm{~h}$ at $-70^{\circ} \mathrm{C}$ with a regular intensifying screen.

Dot-blot hybridization. Total chromosomal DNA was diluted appropriately, heated for $5 \mathrm{~min}$ at $95^{\circ} \mathrm{C}$ and chilled for $2 \mathrm{~min}$ in ice prior to application on to Hybond-N nylon filter using a dot-blot apparatus (Schleicher \& Schuell, Minifold ${ }^{\mathrm{TM}}$ ). The filters were then treated for $1 \mathrm{~min}$ with $0.5 \mathrm{M}-\mathrm{NaOH}$ containing $1.5 \mathrm{M}-\mathrm{NaCl}$, neutralized with $0.5 \mathrm{M}$ Tris/ $\mathrm{HCl}$ buffer (pH 7.2) containing $1.5 \mathrm{M}-\mathrm{NaCl}$ and $0.001 \mathrm{M}$ EDTA and washed in $2 \times$ SSC. The DNA was then bound to the filter using UV. Hybridizations were carried out as described under Southern hybridization (see above).

\section{RESULTS}

\section{Construction of a genomic library for C. jejuni and isolation of the DNA probe}

In deciding which particular DNA sequence might be cloned with a view to its use as a specific DNA probe for identification, a DNA sequence encoding a membrane antigen seemed especially suitable because of the characteristic membrane protein profiles displayed by membrane preparations of $C$. jejuni on SDS-PAGE, which are distinct from those shown by other Campylobacter species (Logan \& Trust, 1982; Blaser et al., 1983; Ferguson \& Lambe, 1984). As these proteins were also known to be immunogenic (Logan \& Trust, 1983), it was assumed that the products of any cloned gene(s) encoding the membrane antigens could be identified immunologically. A genomic library of $C$. jejuni was constructed as follows. Total chromosomal DNA from $C$. jejuni strain FF3 was isolated and partially digested with the restriction enzyme Sau3A to generate DNA fragments in the size range of 5-15 kb. These fragments were fractionated according to size in a sucrose gradient. Suitably sized ones were cloned into the single BamHI site in the Tc resistance gene of the vector plasmid pBR322 (Bolivar et al., 1977), which had been treated with alkaline phosphatase to prevent vector selfligation. The ligation mixture was used to transform $E$. coli strain $\mathrm{DH} 1$ and $\mathrm{Ap}^{\mathrm{R}}$ transformants were selected. From $2786 \mathrm{Ap}^{R}$ transformants, 2597 were $\mathrm{Ap}^{\mathrm{R}} \mathrm{Tc}^{\mathrm{S}}$. These transformants, which were expected to carry recombinant plasmids with inserts of $C$. jejuni chromosomal DNA, were screened immunologically to detect the presence of recombinant plasmids expressing $C$. jejuni antigens. Heterologous polyclonal antiserum raised to whole cells of $C$. jejuni strain CSIRO 18 was used to screen the genomic library made from $C$. jejuni strain FF3 to exclude the selection of transformants bearing recombinant plasmids expressing strain-specific $C$. jejuni antigens. Transformants reacting with whole-cell antiserum were screened again with antiserum raised against membranes of strain CSIRO 18. This served a twofold purpose. Firstly, to aid identification of positively reacting transformants with both antisera and secondly, to ensure that recombinant plasmids chosen were most likely to encode membrane antigens. Eight clones reacting weakly with both whole cell and membrane antisera were identified by colony immunoblotting. Plasmid DNA extracted from them was purified by ultracentrifugation in caesium chloride gradients containing ethidium bromide. Restriction endonuclease cleavage of three of these recombinant plasmids using a panel of enzymes facilitated the construction of restriction maps (Fig. 1). The plasmids carried a common DNA segment. Thus, the polyclonal antibodies facilitated the isolation of recombinant plasmids carrying a DNA segment presumably encoding one of the surface antigens of $C$. jejuni. Of the three recombinant plasmids, pMO2005 was chosen for use as a probe because it carried the smallest chromosomal insert of $C$. jejuni DNA $(6 \cdot 1 \mathrm{~kb}$; Fig. 1$)$.

\section{Probe specificity of cloned $C$. jejuni chromosomal DNA}

Plasmid pMO2005 was nick-translated and used in Southern hybridization against chromosomal DNA digested with $B g I I I$ of a collection of $C$. jejuni strains isolated from a variety of geographical sources, including the strain used for the cloning of $C$. jejuni chromosomal DNA, namely strain FF3, and the reference strain NCTC 11351 (Fig. 2). Very strong hybridization was observed between pMO2005 and all the C. jejuni strains tested. As expected hybridization was not observed between pMO2005 and chromosomal DNA from the $E$. coli cloning host DH1. Neither was hybridization observed between pBR322 and any of the $C$. jejuni strains (data not 
$6 \cdot 1 \mathrm{~kb}$

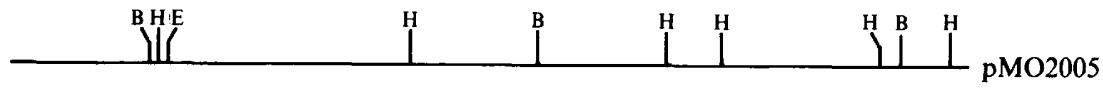

$6 \cdot 5 \mathrm{~kb}$
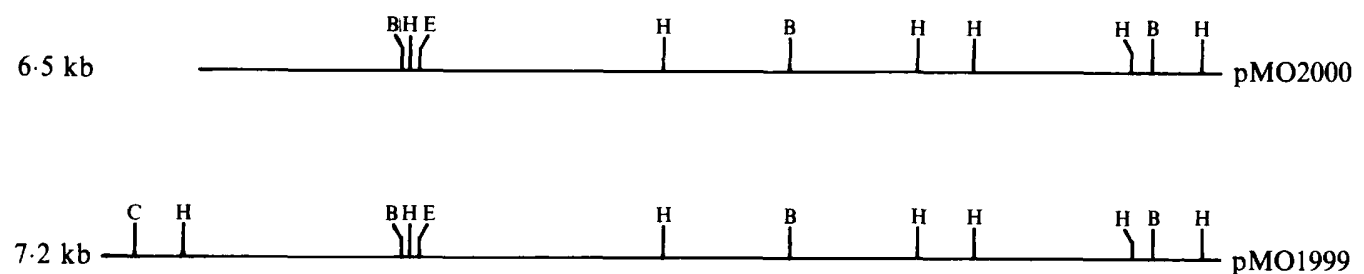

Fig. 1. Restriction endonuclease cleavage maps of the $C$. jejuni chromosomal DNA fragments inserted in vector plasmid pBR322 to produce the named recombinant plasmids. Only the physical maps of the inserts are shown. The sizes of the inserts are indicated. B, BgIII; C, ClaI; E, EcoRV; H, HindIII.

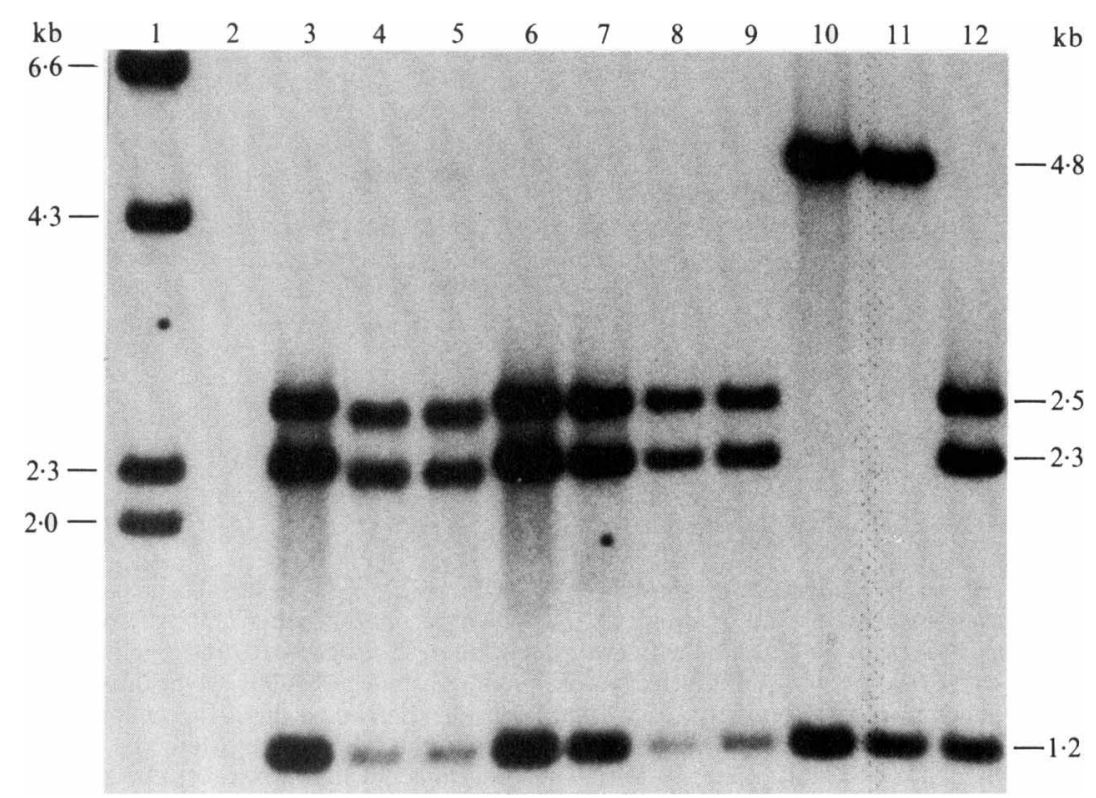

Fig. 2. Southern hybridization of plasmid pMO2005 with Bg/II-digested chromosomal DNA of $C$. jejuni. An autoradiograph is shown of $C$. jejuni chromosomal DNA after digestion with Bg/II, electrophoresis in agarose, transfer to Hybond- $\mathrm{N}$ nylon filters and hybridization with ${ }^{32} \mathrm{P}$-labelled recombinant plasmid pMO2005. Hybridization was under the stringent condition of $65^{\circ} \mathrm{C}$ in SSCP (see Methods) and the filters were washed twice in $2 \times \mathrm{SSC}$ (see Methods) and once in $2 \times \mathrm{SSC}$ with $0.1 \%$ SDS and finally in $0 \cdot 1 \times$ SSC. Lane $1, M_{\mathrm{r}}$ standard, ${ }^{32}$ P-labelled phage $\lambda$ DNA digested with HindIII; lane 2, E. coli strain DH1 chromosomal DNA digested with Bg/II; lanes 3-12, C. jejuni chromosomal DNA digested with BglII (lane 3, strain FF3; lane 4, strain FF1; lane 5, strain FF2; lane 6, strain FF6; lane 7, reference strain NCTC 11351; lane 8, strain 396; lane 9, strain D114; lane 10, strain D117; lane 11 , strain D123; lane 12, strain 80-104). On the left are $\lambda$ fragment sizes and on the right are the sizes of $C$. jejuni chromosomal DNA fragments which hybridize with the probe.

shown). Chromosomal DNA from all of the $C$. jejuni strains yielded a common $1.2 \mathrm{~kb} B g / \mathrm{II}$ fragment. In addition all of the $C$. jejuni strains except strains D117 and D123 revealed two additional $B g / \mathrm{II}$ fragments of $2.3 \mathrm{~kb}$ and $2.5 \mathrm{~kb}$. The exceptional strains yielded, instead, a single additional $B g / \mathrm{II}$ fragment of $4.8 \mathrm{~kb}$. We interpret this result to mean that in these strains the contiguous $2.3 \mathrm{~kb}$ and $2.5 \mathrm{~kb}$ fragments which add up to $4.8 \mathrm{~kb}$ (Fig. 1) have the central $B g / \mathrm{II}$ site missing and that this $B g / \mathrm{II}$ site appears to be polymorphic in the $C$. jejuni strains tested. 

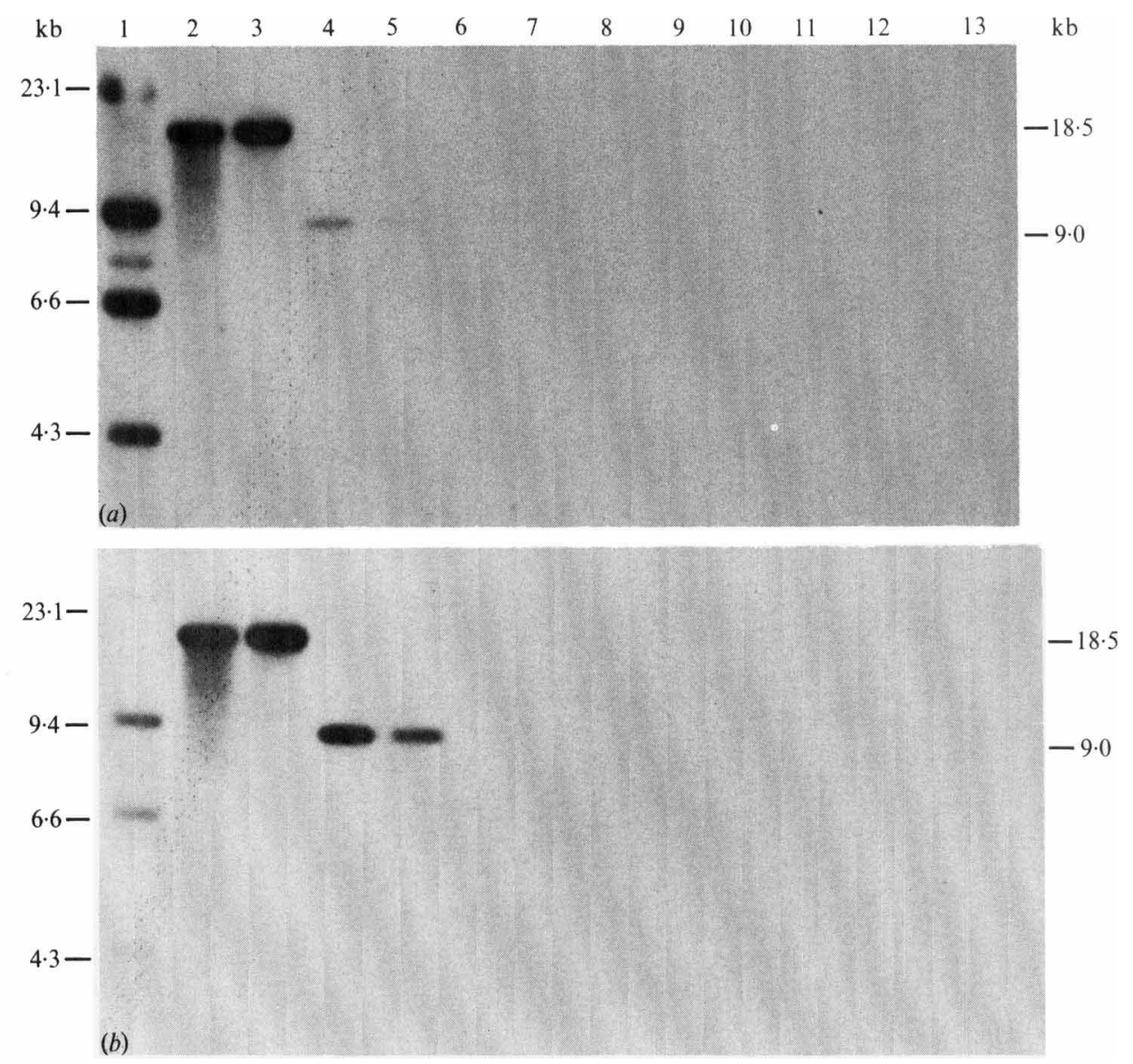

Fig. 3. Southern hybridization of plasmid pMO2005 with ClaI-digested chromosomal DNA of Campylobacter species. An autoradiograph is shown of chromosomal DNA from a range of Campylobacter species after digestion with ClaI, electrophoresis in agarose, transfer to Hybond-N nylon filters and hybridization with ${ }^{32} \mathrm{P}$-labelled recombinant plasmid $\mathrm{pMO} 2005$. Hybridization was under the stringent conditions of $65^{\circ} \mathrm{C}(a)$ and $55^{\circ} \mathrm{C}(b)$. Hybridization under the stringent condition of $65^{\circ} \mathrm{C}$ was in SSCP (see Methods) and the filters were washed twice in $2 \times \operatorname{SSC}$ (see Methods) and once in $2 \times$ SSC with $0.1 \%$ SDS and finally in $0.1 \times$ SSC. The low stringency hybridization at $55^{\circ} \mathrm{C}$ was done and washed in the same solutions as for $65^{\circ} \mathrm{C}$ except that the final wash was omitted. Lane 1, $M_{\mathrm{r}}$ standard, ${ }^{32}$ P-labelled phage $\lambda$ DNA digested with HindIII; lane 2, C. jejuni strain FF3; lane 3, C. jejuni strain 80104; lane 4, C. coli reference strain NCTC 11366; lane 5, C. coli strain 900; lane 6, C. laridis reference strain NCTC 11352; lane 7, C. laridis strain 011; lane 8, C. fetus subsp. fetus reference strain NCTC 10842; lane 9, C. fetus subsp. fetus strain 80-256; lane 10, C. fetus subsp. venerealis reference strain NCTC 10354; lane 11,C. fetus subsp. venerealis strain DI 133; lane 12, 'C. fecalis' reference strain NCTC 11415; lane 13, C. pyloridis strain P2. On the left are $\lambda$ fragment sizes and on the right are the sizes of Campylobacter chromosomal DNA fragments which hybridize with the probe.

To test the specificity of the probe, plasmid pMO2005 was used as a probe in Southern hybridization against ClaI-digested chromosomal DNA of strains belonging to a selection of other species of Campylobacter, including $C$. coli and C. laridis, which are also known to be pathogenic to man (Skirrow, 1982; Tauxe et al., 1985) (Fig. 3). The restriction endonuclease ClaI was used rather than $B g l I I$ in order to reduce the number of hybridizing bands in the analysis. It can be seen that, as expected, a strong hybridization signal was observed with an $18.5 \mathrm{~kb}$ ClaI fragment of chromosomal DNA of $C$. jejuni strain FF3, but relatively weak hybridization was also observed with a $9.0 \mathrm{~kb}$ ClaI fragment from C. coli reference strain NCTC 11366 and strain 900. There was no detectable hybridization between the plasmid probe and chromosomal DNA 
from any of the other species of Campylobacter even after prolonged exposure $(72 \mathrm{~h})$ of the autoradiograph. Thus the cloned $C$. jejuni chromosomal DNA was highly specific for $C$. jejuni but with a much weaker level of cross-hybridization with $C$. coli. In addition to the strains shown in Fig. 2, 14 other clinical isolates of $C$. jejuni from the Fairfield Infectious Diseases Hospital, Victoria, Australia were tested using plasmid pMO2005 as probe. These tests were done by dotblot hybridization using in situ lysed cell cultures. By this test as well, all 14 showed positive signals with the probe (data not shown).

When the specificity of the pMO2005 probe was tested against chromosomal DNA of a selection of other bacteria likely to be encountered from the same clinical environment as $C$. jejuni, there was no detectable hybridization under varying stringency conditions of 45,55 or the standard $65^{\circ} \mathrm{C}$ (data not shown). These bacteria were Salmonella typhimurium, Salmonella enteritidis, Enterobacter cloacae, Klebsiella pneumoniae, Citrobacter freundii, Vibrio parahaemolyticus, enteropathogenic E. coli O111:K58(B4), Shigella sonnei, Serratia marcescens, Proteus vulgaris and Pseudomonas aeruginosa.

To test whether strong hybridization between the $C$. jejuni probe pMO2005 and $C$. coli strains could be demonstrated, which might be useful in diagnosis and in epidemiology, the stringency of hybridization was relaxed by doing the hybridizations at 55 instead of $65^{\circ} \mathrm{C}$. Under these conditions hybridization signals in the heterologous combination with $C$. coli reference strain NCTC 11366 and strain 900 were observed (Fig. 3b), which were as strong as those in the homologous combination with $C$. jejuni strain FF3 (Fig. $3 a$ ). The pMO2005 probe hybridized to $9.0 \mathrm{~kb}$ ClaI fragments of $C$. coli chromosomal DNA instead of to $18.5 \mathrm{~kb}$ Cla I fragments as in the homologous combination. Even under this reduced stringency condition of $55^{\circ} \mathrm{C}$ there was no detectable hybridization between the probe and the chromosomal DNA from the other Campylobacter species.

\section{DISCUSSION}

The important outcome of this investigation was the construction of a highly specific DNA probe for $C$. jejuni by recombinant DNA techniques. The probe reported herein is more specific than those obtained previously (Rashtchian et al., 1986; Steele et al., 1985) and may aid the rapid identification of campylobacteriosis in man. The fact that a much weaker hybridization signal was detectable between the $C$. jejuni probe and chromosomal DNA from $C$. coli strains under the standard high stringency condition of $65^{\circ} \mathrm{C}$ was expected in view of the close similarity between these two species by conventional methods of identification (Hébert et al., 1982, 1984). As both $C$. jejuni and $C$. coli are frequently encountered in human campylobacteriosis, the probe might be useful in the identification of Campylobacter pathogenic to man especially by reducing the stringency condition to $55^{\circ} \mathrm{C}$ (Fig. $3 b$ ). However, the probe pMO2005 that has been constructed, in addition to readily distinguishing $C$. jejuni and $C$. coli from other Campylobacter species and the other Gram-negative bacteria tested here, can additionally be used to distinguish between $C$. jejuni and $C$. coli by the size of chromosomal fragments that hybridize to the probe (Fig. $3 b$ ) and by varying the stringency condition of hybridization (Fig. 3a,b). Thus pMO2005 can be used in epidemiology, particularly where other methods are unable to distinguish between these two species.

Although pMO2005 did not hybridize with genomic DNA of the enteric bacteria tested here, it has to be recognized that the vector plasmid pBR322, being a ColE1-like plasmid, will be expected to hybridize with genomic DNA of some enteric bacteria such as Salmonella because of the ubiquity of this type of plasmid (Tompkins et al., 1986). Therefore, in diagnostic and epidemiological studies for the direct and rapid identification of $C$. jejuni from faecal material the $C$. jejuni chromosomal insert in pMO2005 would need to be freed of the vector and used directly as a probe. In addition, although the Southern hybridization procedure using the probe as shown here may be valuable for the molecular epidemiology of strains which are especially difficult to classify by conventional methods, it would not be feasible to use this procedure for routine diagnostic purposes. For the latter it will be necessary to use dot-blot hybridizations on cells lysed in situ. Current experiments are in progress towards this goal. Furthermore, for safety and ease of use in a routine diagnostic laboratory radioactively labelled probes would not be practical and probes based on non-radioactive reporter groups need to be developed. 
Attempts to determine which of the membrane antigens are encoded by the recombinant plasmid pMO2005 (Fig. 1) by Western immunoblotting (Towbin et al., 1979) and SDS-PAGE (Laemmli, 1970) using protein denaturing and non-denaturing conditions were unsuccessful (data not shown). This was probably due to inefficient expression of $C$. jejuni membrane antigen(s) in E. coli. Furthermore, the $6.1 \mathrm{~kb}$ insert in pMO2005 is likely to encode information for more than a single gene product and one or more of these are being detected by the antisera used in screening the transformants. Other methods of gene-product identification are currently under investigation such as by sub-cloning into $E$. coli expression vectors and maxicell analysis or by expression in Gram-negative bacterial hosts other than $E$. coli.

We thank M. J. Blaser, C. M. Patton, T. W. Steele and W. Tee for their generosity in providing the Campylobacter strains and J. Frey for the E. coli cloning strain. V. Korolik is supported by a Commonwealth of Australia Postgraduate Research Award.

\section{REFERENCES}

BachmanN, B. J. (1983). Linkage map of Escherichia coli. Edition 7. Microbiological Reviews 47, 180-230.

Blaser, M. J. \& Reller, L. B. (1981). Campylobacter enteritis. New England Journal of Medicine 305, 1444-1452.

Blaser, M. J., Hopkins, J. A., Berka, R. M., Vasil, M. L. \& WANG, W. L. (1983). Identification and characterization of Campylobacter jejuni outer membrane proteins. Infection and Immunity 42, 276-284.

Bolivar, F., Rodriguez, R. C., Greene, P. J., Betlach, M. C., Heynecker, H. C., Boyer, H. W., Crosa, J. H. \& Falkow, S. (1977). Construction and characterization of new cloning vehicles. II. A multipurpose cloning system. Gene 2, 95-113.

Bradbury, W. C., Pearson, A. D., Marko, M. A., Congi, R. V. \& Penner, J. L. (1984). Investigation of a Campylobacter jejuni outbreak by serotyping and chromosomal restriction endonuclease analysis. Journal of Clinical Microbiology 19, 343-346.

Claus, P., Moseley, S. L. \& Falkow, S. (1982). The use of gene-specific DNA probes for the identification of enteric pathogens. Progress in Food and Nutrition Science 7, 139-142.

Collins, D. M. \& Ross, D. E. (1984). Restriction endonuclease analysis of Campylobacter strains with particular reference to Campylobacter fetus ss. fetus. Journal of Medical Microbiology 18, 117-124.

Ferguson, D. A. \& LAMBE, D. W. (1984). Differentiation of Campylobacter species by protein banding patterns in polyacrylamide slab gels. Journal of Clinical Microbiology 20, 453-460.

Frey, J., Bagdasarian, M., Feiss, D., Franklin, F. C. H. \& Deshusses, J. (1983). Stable cosmid vectors that enable the introduction of cloned fragments into a wide range of Gram-negative bacteria. Gene 24, 299-308.

Grimont, P. A. D., Grimont, F., Desplaces, N. \& TCHEN, P. (1985). DNA probe specific for Legionella pneumophila. Journal of Clinical Microbiology 21, 431-437.

Hébert, G. A., Hollis, D. G., Weaver, R. E., LAmbert, M. A., Blaser, M. J. \& Moss, C. W. (1982). 30 years of campylobacters, biochemical characteristics and a biotyping proposal for Campylobacter jejuni. Journal of Clinical Microbiology 15, 1065-1073.
Hébert, G. A., Edmonds, P. \& Brenner, D. J. (1984). DNA relatedness among strains of Campylobacter jejuni and Campylobacter coli with divergent serogroup and hippurate reactions. Journal of Clinical Microbiology 20, 138-140.

Krishnapillai, V., Nash, J. \& Lanka, E. (1984). Insertion mutations in the promiscuous IncP-1 plasmid R18 which affect its host range between Pseudomonas species. Plasmid 12, 170-180.

LAEMMLI, U. K. (1970). Cleavage of structural proteins during the assembly of the head of bacteriophage T4. Nature, London 227, 680-685.

Logan, S. M. \& TRUST, T. J. (1982). Outer membrane characteristics of Campylobacter jejuni. Infection and Immunity 38, 898-906.

Logan, S. M. \& Trust, T. J. (1983). Molecular identification of surface protein antigens of Campylobacter jejuni. Infection and Immunity 42, 675-682.

Maniatis, T., Fritsch, E. F. \& Sambrook, J. (1982). Molecular Cloning, A Laboratory Manual. Cold Spring Harbor, NY: Cold Spring Harbor Laboratory.

Mills, D. S. \& BradbuRY, W. C. (1984). Human antibody response to outer membrane proteins of Campylobacter jejuni during infection. Infection and Immunity 43, 739-743.

OWEN, R. J. \& DAwson, C. (1986). DNA base compositions and base sequence relatedness of atypical Campylobacter jejuni strains from clinical material. FEMS Microbiology Letters 35, 283-287.

Penner, J. L., Hennessy, J. N. \& Congi, R. V. (1983). Serotyping of Campylobacter jejuni and Campylobacter coli on the basis of thermostable antigens. European Journal of Clinical Microbiology 2, 278-283.

Rashtchian, A., ABbotT, M., Lovern, D. H., MOCK, G. A. \& ShafFer, M. M. (1986). Use of synthetic oligonucleotides complementary to rRNA for detection of Campylobacter. Abstracts of the Annual Meeting of the American Society for Microbiology, abstract no. C-90, p. 343.

Rubin, F. A., Kopecko, D. J., NoON, K. F. \& BARON, L. S. (1985). Development of a DNA probe to detect Salmonella typhi. Journal of Clinical Microbiology 22, 600-605.

SkIRRow, M. B. (1982). Campylobacter enteritis - the first five years. Journal of Hygiene 89, 175-184. 
Skirrow, M. B., Benjamin, J., Razi, M. H. H. \& WATERMAN, S. (1982). Isolation, cultivation and identification of Campylobacter jejuni and C. coli. In Isolation and Identification Methods for Food Poisoning Organisms, Society for Applied Bacteriology Technical Series no. 17, pp. 313-323. Edited by J. E. L. Corry, D. Roberts \& F. A. Skinner. London: Academic Press.

Smith, G. E. \& Summers, M. D. (1980). The bidirectional transfer of DNA and RNA to nitrocellulose or diazobenzyloxymethyl-paper. Analytical Biochemistry 109, 123-129.

Steele, T. W., SANGster, N. \& Lanser, J. A. (1985). DNA relatedness and biochemical features of Campylobacter spp. isolated in Central and South Australia. Journal of Clinical Microbiology 22, 71-74.
Tauxe, R. V., Patton, C. M., EdMonds, P., Barrett, T. J., Brenner, D. J. \& Blake, P. A. (1985). Illness associated with Campylobacter laridis, a newly recognized Campylobacter species. Journal of Clinical Microbiology 21, 222-225.

Tompkins, L. S., Troup, N., Labigne-Rousel, A. \& COHEN, M. L. (1986). Cloned, random chromosomal sequences as probes to identify Salmonella species. Journal of Infectious Diseases 154, 156-162.

Towbin, H., Staehelin, T. \& Gordon, J. (1979). Electrophoretic transfer of proteins from polyacrylamide gels to nitrocellulose sheets, procedure and some applications. Proceedings of the National Academy of Sciences of the United States of America 76, 4350-4354. 